\title{
Effect of different agro-wastes, casing materials and supplements on the growth, yield and nutrition of milky mushroom (Calocybe indica)
}

\author{
Hasan Sardar*, Muhammad Akbar Anjum, Aamir Nawaz, Safina Naz*, \\ Shaghef Ejaz, Sajid Ali, SakeenaTul-Ain Haider
}

Department of Horticulture, Faculty of Agricultural Sciences and Technology, Bahauddin Zakariya University, 60800 Multan, Pakistan

\begin{abstract}
Agricultural waste disposal is one of the main concerns in today's world that can cause environmental pollution. Utilisation of agro-waste materials to grow mushrooms is an eco-friendly method to reduce pollution. Therefore, various agricultural waste materials, such as wheat straw, rice straw and cotton waste, were utilised for the production of milky mushroom. Among the substrates used in this study wheat straw showed superior substrate for the production of milky mushroom. The agronomic traits studied such as total yield, number of fruiting bodies, the maximum diameter of pileus and stalk length, biological efficiency, protein contents, phosphorous and potassium contents were observed on wheat straw substrate. Peat moss, loam soil and spent mushroom substrate were used as casing materials. Among the casing materials used, the highest yield and biological efficiency were observed on peat moss. The results also indicated that the addition of supplements with the substrate improved yield and yield contributing characteristics. Among the tested supplements (wheat bran and rice bran), wheat bran was the best supplement for wheat straw substrate to cultivate milky white mushroom.
\end{abstract}

Keywords: agro-waste materials, biological efficiency, casing materials, Milky mushroom, supplements

\section{INTRODUCTION}

Mushrooms are appreciated in most of the countries due to their delicacy, flavour, taste and texture and are considered as an ideal health food (Stamets, 2011). Mushroom cultivation is gaining popularity among growers in urban and peri-urban areas due to inexpensive raw materials including agriculture and industrial waste (Chang, 2007). Mushrooms are considered as a rich source of protein (20-40\%) on a dry weight basis (Kurtzman, 2005), dietary fibres, minerals (P, K, $\mathrm{Na}, \mathrm{Ca}$ and $\mathrm{Fe}$ ), vitamins such as $\mathrm{B} 1, \mathrm{~B} 2, \mathrm{~B} 12$, niacin, folate and ascorbic acid (Mattila et al., 2001) and amino acids while being low in fats. Mushrooms have been renowned also due to high medicinal properties such as anti-ageing, antiviral, antioxidative, anti-hypertensive, antimicrobial, antibacterial, antifungal, anticancer, antitumour, anti-inflammatory and antihypotensive (Patel et al., 2012).

Milky mushroom (Calocybe indica) is becoming more popular in many parts of the world due to its robust size, attractive milky appearance, delicious taste, attractive colour, excellent shelf life and unique texture besides having sustainable yield (Chang, 2007; Alam et al., 2010). Milky mushroom is a relatively new addition to the world of edible mushrooms since most of the edible mushrooms (oyster and button mushroom) require low temperature $\left(<25^{\circ} \mathrm{C}\right)$ for their commercial cultivation. In warm regions, the cultivation of mushrooms is always expensive due to 
the requirement of certain infrastructure (Thakur and Singh, 2014). Identification and cultivation of warmweather $\left(30 \sim 38^{\circ} \mathrm{C}\right)$ varieties of edible mushrooms have been a scientifically challenging task. Milky mushroom, having high-temperature requirements of $30-35^{\circ} \mathrm{C}$ as compared to other cultivated mushrooms, can be cultivated in hot humid climate throughout the summer season (Pani, 2010; Kumar et al., 2012).

Temperature, amount of moisture in the air as well as in substrate, growing substrate type, spawn age and percentage, culture media, carbon dioxide and oxygen in growth room, air circulation, substrate $\mathrm{pH}$, carbonnitrogen ratio in substrate and supplements affect the growth of mushroom (Kadiri, 1999; Sardar et al., 2015). It is necessary to find the appropriate culture media, temperature, $\mathrm{pH}$ and substrate for higher yield and nutrition of cultivated mushroom. Mushroom fruiting body development depends on lignocellulosic waste material that provides nutrition such as carbon and nitrogen for growth (Miles and Chang, 2004). A large variety of diverse agricultural waste materials including wheat straw, peanut waste, cotton waste, paper waste, olive mill waste, banana leaves, sawdust, sugarcane bagasse, corncobs, coffee waste, soybean straw, peanut hull, and so on are used for cultivation of mushroom (Krishnamoorthy et al., 2000; Amin et al., 2010; Sardar et al., 2017).

In commercial cultivation of milky mushroom, casing is an important agronomic practice on which fruit bodies appear. The casing layer is used to cover the compost after the germination phase and stimulate the transition from vegetative to reproductive growth (Pardo et al., 2004). Casing materials must have high water holding capacity, a good air space ratio to facilitate gaseous exchange, porosity and bulk density (Yadav, 2006). Several casing materials were used by various researchers for mushroom cultivation such as peat moss, loam soil, spent mushroom substrate, coconut coir, biogas slurry, farmyard manure, and so on (Krishnamoorthy et al., 2000). In addition to the casing layer, substrates are supplemented with various materials to influence the spawn run, yield and biological efficiency. Several supplementing materials, such as cotton cake, soybean flour, maize powder, wheat bran, mustard cake, cottonseed, pigeon pea powder, lentil powder, gram powder, neem cake, rice bran, loam soil, spent mushroom substrate, and so on, were used by many workers to enhance the yield and biological efficiency of mushroom (Alam et al., 2010; Amin et al., 2010; Kumar et al., 2012).

Oyster and button mushrooms, which require low temperature $\left(18-20^{\circ} \mathrm{C}\right)$ for its growth and production, can only be cultivated during winter months or under controlled conditions (Chang, 2008). The major challenge for mushroom cultivation is maintaining low temperature during the months of summer which ranges between 27 and $45^{\circ} \mathrm{C}$ (Miles and Chang, 2004). If facilities of low-temperature control are not available during summer months, it necessitates the selection for cultivable mushroom species that are tolerant to high temperature. Milky mushroom is one of the best edible mushrooms which is grown at high temperature during summer months (Vijaykumar et al., 2014). However, there is a need to specify substrates for the cultivation of milky mushroom. Therefore, this study was carried out to determine the best temperature, $\mathrm{pH}$ requirement, substrate, casing material and supplementing material for the cultivation of milky mushroom.

\section{MATERIALS AND METHODS}

Four experiments were conducted in this study. In the first experiment, the mycelial growth of mushroom was recorded at different temperatures, agar media and $\mathrm{pH}$ levels. The second experiment was conducted to assess the best growing substrate for nutritional and agronomic characteristics of milky mushroom. The third experiment tested the influence of various casing constituents on the yield and biological efficiency of milky mushroom. In the fourth experiment, supplements were used in substrates for enhancing the growth and yield of milky mushroom.

\section{Mushroom strain and substrates collection}

Milky mushroom C. indica of Indian origin (Pani, 2010) culture was revived from an already present pure culture. Substrates (waste materials), such as rice straw (chopped), wheat straw and cotton waste, were obtained from the surroundings of Multan.

\section{Experiment No. 1}

\section{Effect of different agar media, temperature and pH levels on the mycelial growth of milky mushroom (C. indica)}

Two types of agar media, that is potato dextrose agar (PDA) and malt extract agar (MEA), were used for the mycelial development at various temperature levels, that is, $25^{\circ} \mathrm{C}, 30^{\circ} \mathrm{C}$ and $35^{\circ} \mathrm{C}$.

\section{Culture preparation}

For the preparation of PDA was prepared by boiling $200 \mathrm{~g}$ peeled potatoes in $1 \mathrm{~L}$ water, and extract of potato mixed with $20 \mathrm{~g}$ agar and $20 \mathrm{~g}$ dextrose in $1 \mathrm{~L}$ distilled water. Similarly, the MEA medium was prepared by mixing $20 \mathrm{~g}$ agar, $20 \mathrm{~g}$ dextrose and $20 \mathrm{~g}$ malt extract in $1 \mathrm{~L}$ distilled water. Both mediums were poured in volumetric flasks separately and autoclaved to kill microorganisms. The prepared and sterilised media were poured $(20 \mathrm{~mL})$ in $90 \mathrm{~mm}$ petri dish separately. After solidification of media in petri dish, mushroom culture was inoculated at the centre of the petri dish with $5 \mathrm{~mm}$ disc of actively growing mycelium under aseptic conditions with three replications. Mycelium growth in the petri dish was measured after 9 days of inoculated. 


\section{pH optimisation of agar media for mycelial growth of milky mushroom}

After standardisation of agar media and temperature, $\mathrm{pH}$ was optimised by using $\mathrm{HCL}$ and $\mathrm{NaOH}$. The $\mathrm{pH}$ of the media was set at different $\mathrm{pH}$ levels $(6,7$ and 8) after sterilisation of media in autoclave (Automatic Drying Autoclave ATV1100) at $121^{\circ} \mathrm{C}$. Mycelial growth (cm) was also recorded after 9 days of inoculation (Hoa et al., 2015).

\section{Spawn preparation}

Spawn was prepared for the cultivation of milky mushroom. Spawn of milky mushroom was prepared according to the method described by Sardar et al. (2017) with little modifications. Instead of using millet grains, wheat grains were used for the covering of mycelium on them. The wheat grains were half-boiled at $100^{\circ} \mathrm{C}$ for $30 \mathrm{~min}$ (Ruiz-Rodríguez et al., 2011). The $\mathrm{pH}$ of the spawn was maintained by adding $\mathrm{CaCO}_{3}$ and $\mathrm{CaSO}_{4}$ in wheat grain. Before inoculating the grains with mycelium grains were autoclaved at $121^{\circ} \mathrm{C}$ and pressure 15 psi for $30 \mathrm{~min}$ to kill the microorganisms and to sterilise grains. The mycelium-coated grains were filled in polythene bags of $1 \mathrm{~kg}$ and placed for complete covering of mycelium at temperature $30 \pm 2{ }^{\circ} \mathrm{C}$. The mycelium took 18-20 days to completely cover the grains.

\section{Experiment No. 2}

\section{Evaluation of various substrates for the cultivation of milky mushroom}

\section{Substrates preparation}

Substrates for the cultivation of milky mushroom were prepared according to the method described by Amin et al. (2010) with little alterations. The substrates were soaked in water for $24 \mathrm{~h}$ and then spread on the floor to constitute the level of moisture at $65 \%$ (determined by using hot air oven). The prepared media $(1.5 \mathrm{~kg})$ was filled in transparent polypropylene bags of $25.4 \mathrm{~cm} \times 38.1 \mathrm{~cm}$ size and pasteurised. The mouths of bags were closed with rubber loose band and opened after the completion of mycelium running.

\section{Experimental conditions}

Substrates filled bags were inoculation with 5\% spawn and then incubated at $30^{\circ} \mathrm{C}$ for mycelium growth in the mushroom growth room. After the completion of mycelium growth in the bags with fungus, $2.5 \mathrm{~cm}$ thick layer of casing material was applied uniformly on the substrate. The average relative humidity was maintained at above $85 \%$ and the temperature range was set between 30 and $35^{\circ} \mathrm{C}$. Humidity was maintained with the help of humidifier (SINBO Hislon SAH-6107). Furthermore, fresh air in the growing room was circulated with an exhaust fan (size 12 inch) to lower the $\mathrm{CO}_{2}$ below $1,000 \mathrm{ppm}$ after every $3-4 \mathrm{~h}$.

\section{Data recorded}

The mushroom fruiting bodies were harvested after 25 days (on fruiting body maturity), and observations on growth parameters were recorded. The following data were recorded during the experiment.

\section{Growth attributes}

Mushroom growth attributes such as time taken to complete mycelium running of bags in days (colonisation of substrate with white mycelium which can be seen through transparent polythene bags), stalk diameter $(\mathrm{cm})$, stalk length $(\mathrm{cm})$, number of fruiting bodies harvested, fruiting body fresh weight $(\mathrm{g})$, pileus diameter $(\mathrm{cm})$, total yield $(\mathrm{g} / \mathrm{bag})$ and biological efficiency $=($ total $\mathrm{yield}$ obtained from individual bag/dry weight of substrate used $\times 100$ ) expressed as percentage (Royse et al., 2004).

\section{Mushroom quality characteristics}

Moisture percentage, protein contents, nitrogen and potassium were analysed according to the method of AOAC (1990). Moisture content was determined by drying fresh samples until constant weight at $105^{\circ} \mathrm{C}$ in a hot air oven. The nitrogen content was determined by micro Kjeldahl method and protein content $(\mathrm{N} \times 6.24)$ expressed as percentage (Hoa et al., 2015). The ash content was estimated from the sample incinerated at $600 \pm 15^{\circ} \mathrm{C}$ (Raghuramulu et al. 2003). Phosphorus was measured according to the procedure as previously described by Chapman and Parker (1961).

\section{Substrates chemical analysis}

Substrates used for the cultivation of milky mushroom were chemically analysed for nitrogen, phosphorous and potassium before inoculation and after harvesting the mushrooms. The analysis was performed as described for the mushroom fruiting bodies analysis (AOAC, 1990).

\section{Experiment No. 3}

\section{Influence of various casing materials on the yield and biological efficiency of milky mushroom}

Effect of casing materials, that is peat moss, spent mushroom substrate and loam soil on the growth of mushroom, was evaluated. Wheat straw was used as a substrate in this experiment on the basis of the evaluation of the substrates during Experiment No. 2. Experimental conditions and substrate preparation methods were the same as in Experiment No. 2. All the casing materials were subjected to therm treatment at $65^{\circ} \mathrm{C}$ for $4 \mathrm{~h}$. After therm treatment of casing materials, they were spread on the bags upon completion of mycelium running. A $2.5 \mathrm{~cm}$ thick layer of casing material was applied uniformly on the substrate. The following parameters were recorded for this experiment: number of fruiting bodies harvested from per bag, total yield obtained from per bag and biological efficiency in percentage. 


\section{Experiment No. 4}

\section{Effect of various supplementation on the agronomic characteristics of milky mushroom}

Effects of various easily available supplementation materials (i.e. wheat bran and rice bran) were tested with substrate (wheat straw) on the growth of milky mushroom. The supplements were sun-dried and sterilised in an autoclave at $121^{\circ} \mathrm{C}$ for $20 \mathrm{~min}$. Each of the supplements ( $4 \%$ dry weight) was mixed separately with substrate (wheat straw) before spawning. The substrates were filled in the bags, and spawning was done as described in Experiment No. 2 with the same experimental conditions. The following observations were recorded: days to complete mycelium running of substrate filled bags, number of mature fruiting bodies harvested from per bag, total yield obtained per bag in grams and biological efficiency expressed as percentage.

\section{Statistical analysis}

Data collected were analysed using the Statistix 8.1 software. One way ANOVA was performed using the LSD test at $p<0.05$, and the mean of each parameter was compared. All the experiments were conducted in a completely randomised design with three replications of each treatment.

\section{RESULTS AND DISCUSSION}

\section{Experiment No.1 (a): Influence of temperature and agar media on mycelial growth of $C$. indica}

The effects of two different culture medium (PDA and MEA) on mycelial growth of $C$. indica at different temperature levels were recorded after 10 days of inoculation (Figure 1). The temperature significantly influenced the mycelial growth of $C$. indica on both PDA and MEA mediums. The maximum mycelial growth $(8.43 \mathrm{~cm})$ was observed at $30^{\circ} \mathrm{C}$ on PDA media, while the minimum growth of mushroom mycelium $(6.43 \mathrm{~cm})$ was measured at $35^{\circ} \mathrm{C}$ on MEA media (Figure 1). Both PDA and MEA media gave the maximum growth (8.43 $\mathrm{cm}$ and $7.73 \mathrm{~cm}$, respectively) at $30^{\circ} \mathrm{C}$. With the increase in temperature during incubation from 25 to $35^{\circ} \mathrm{C}$, mycelial growth of milky mushroom was highly influenced. However, the interaction effect of media and temperature on mycelial growth was non-significant. There were non-significant differences in the mean growth rate of mycelium among the media (Figure 1). However, PDA gave higher mycelial growth $(7.46 \mathrm{~cm})$ than MEA $(7.04 \mathrm{~cm})$. The temperature of the incubation affects mycelial growth of fungus as other biological growth process influenced (Zadrazil, 1978). In the present study, mycelial growth was maximal at $30^{\circ} \mathrm{C}$ on both agar media. These results are in agreement with those of Shukla and Jaitly (2013) and Singh et al. (2015) who obtained the maximum mycelial growth of milky mushroom at $30^{\circ} \mathrm{C}$. Varshney (2007) and Subbiah and Balan (2015) reported $25-35^{\circ} \mathrm{C}$ temperature is ideal for the highest growth of mycelium of the milky mushroom.

\section{Experiment No.1 (b): Influence of different pH levels of growth media on mycelial growth of C. indica}

The influence of $\mathrm{pH}$ variations on the mycelial growth of milky mushroom is shown in Figure 2. PDA media was used in this experiment with $\mathrm{pH}$ levels of 6, 7 and 8. There was a significant difference in the growth of mycelia of milky mushroom as shown in Figure 2. The maximum mycelial growth of $C$. indica $(8.63 \mathrm{~cm})$ was measured at $\mathrm{pH} 7$, while the $\mathrm{pH} 8$ level of agar media showed minimum mycelial growth $(6.76 \mathrm{~cm})$. Mycelial growth was adversely affected either with an increase or decrease in $\mathrm{pH}$ levels. The results are nearly comparable with the results of Arshukla (2004) who stated that $\mathrm{pH}$ 7 of agar media showed the highest mycelial growth of milky mushroom, while Subbiah and Balan (2015) found optimal mycelial growth of mushroom within the range of 5.5 and 8.5 .

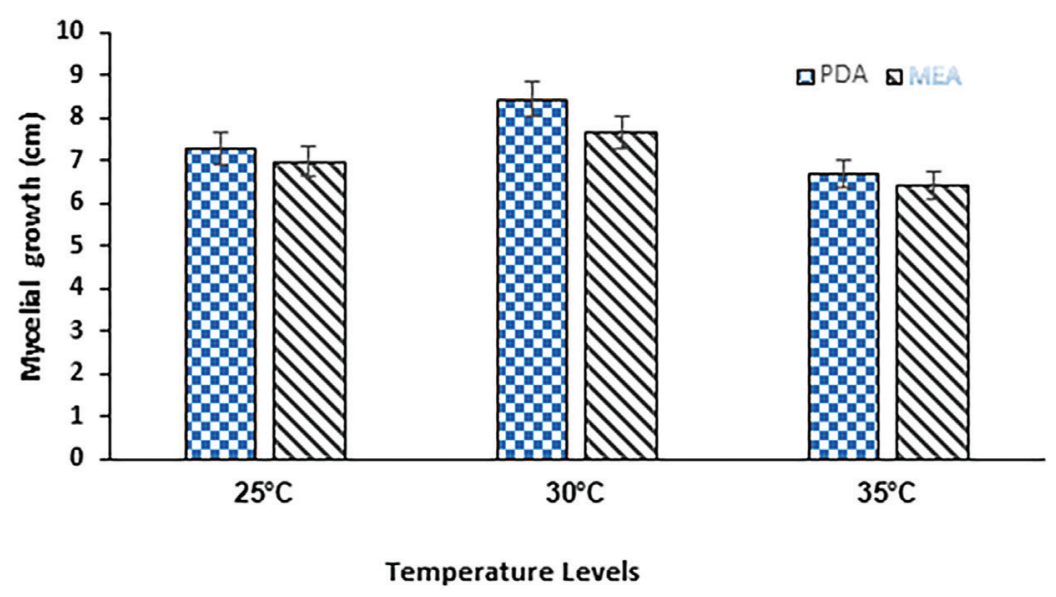

Figure 1. The mycelial growth $(\mathrm{cm})$ of Calocybe indica on different media at different temperature levels. Vertical bars represent mean $\pm \mathrm{SE}(n=3)$. 


\section{Experiment No. 2}

\section{Influence of different substrates on the yield and nutritional value of milky mushroom}

\section{Growth attributes}

As summarised in Tables 1 and 2, three different substrates were tested for the highest yield and nutritional components of milky mushroom. The time required to complete mycelium running in days differs significantly $(p<0.05)$ among substrates. In this study, mycelial running was significantly earliest in wheat straw substrate (23 days) followed by rice straw (28.33 days), whereas significantly maximum time was required in cotton waste (34 days). The results suggest that wheat straw substrate is the best substrate for the fastest colonisation of milky mushroom. Similar to these findings, Vijaykumar et al. (2014) reported that wheat straw is the best substrate for the fastest mycelium colonisation as compared to other substrates. They stated that a high amount of lignin, hemi-cellulose, pectin in the wheat straw substrate accelerate the high rate of mycelium of milky mushroom. Moreover, suitable carbon to nitrogen ratio might have been responsible for the higher mycelial growth rate in wheat straw substrate.

The pileus diameter and stem length significantly varied from each other on different substrates, while the stem diameter of mushroom was found non-significant
(Table 1). The maximum stem diameter $(1.93 \mathrm{~cm})$ was observed in wheat straw, followed by cotton waste $(1.60 \mathrm{~cm})$ while the minimum was measured on rice straw $(1.57 \mathrm{~cm})$. Although stem diameter was nonsignificant among substrates, the diameter observed in wheat straw was $\sim 18 \%$ greater than in other substrates. The stem length of $C$. indica was significantly $(p<0.05)$ different on different substrates. The maximum stem length $(8.17 \mathrm{~cm})$ was observed in wheat straw, followed by on rice straw $(7.03 \mathrm{~cm})$, while the minimum stem length was found $(6.53 \mathrm{~cm})$ in cotton waste substrate. Dhakad et al. (2015) observed similar values, whereby stalk length was in the range of 4.74 to $7.81 \mathrm{~cm}$ and diameter of stipe varies from 6.73 to $8.28 \mathrm{~cm}$ in milky mushroom.

Different substrates had a significant influence on number of fruiting bodies (Table 1). The highest number of fruiting bodies per bag was observed in wheat straw (13) followed by rice straw (11), while the lowest (7) in cotton waste substrate. Similarly, the fresh weight of mushroom fruiting bodies differed significantly among substrates. The maximum fresh weight of fruiting body $(37 \mathrm{~g})$ was recorded in wheat straw, while the minimum weight of fruiting body $(28 \mathrm{~g})$ was noted from cotton waste substrate. Regarding total yield obtained after harvesting of all mushrooms from bags, there was a significant difference $(p<0.05)$ among different substrates. The maximum total yield $(493.67 \mathrm{~g})$ was found on wheat straw substrate bags, while the least total

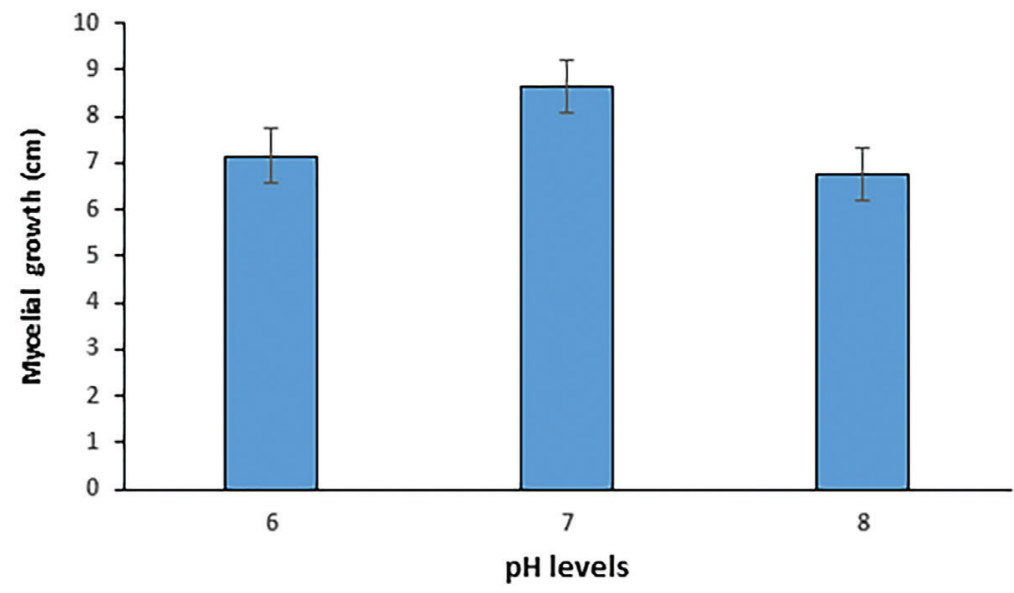

Figure 2. The mycelial growth $(\mathrm{cm})$ of Calocybe indica on PDA at different $\mathrm{pH}$ levels. Vertical bars represent mean $\pm \operatorname{SE}(n=3)$.

Table 1. Effect of different substrates on growth attributes such as mycelial running, number of fruiting bodies per bag, fresh weight of fruiting body, pileus diameter, stem diameter, stem length of Calocybe indica

\begin{tabular}{lcccccc}
\hline Treatment & $\begin{array}{c}\text { Mycelial running } \\
(\text { days })\end{array}$ & $\begin{array}{c}\text { Pileus diameter } \\
(\mathrm{cm})\end{array}$ & $\begin{array}{c}\text { Stem diameter } \\
(\mathrm{cm})\end{array}$ & $\begin{array}{c}\text { Stem length } \\
(\mathrm{cm})\end{array}$ & $\begin{array}{c}\text { Number of fruiting } \\
\text { bodies } / \mathrm{bag}\end{array}$ & $\begin{array}{c}\text { Fresh weigh of } \\
\text { fruiting body }(\mathrm{g})\end{array}$ \\
\hline Wheat straw & $23.00 \pm 0.81 \mathrm{c}$ & $5.05 \pm 0.07 \mathrm{a}$ & $1.93 \pm 0.24 \mathrm{a}$ & $8.17 \pm 0.18 \mathrm{a}$ & $13.00 \pm 0.40 \mathrm{a}$ & $37.99 \pm 0.60 \mathrm{a}$ \\
Rice straw & $28.33 \pm 1.03 \mathrm{~b}$ & $4.51 \pm 0.15 \mathrm{~b}$ & $1.57 \pm 0.08 \mathrm{a}$ & $7.03 \pm 0.20 \mathrm{~b}$ & $11.00 \pm 0.40 \mathrm{a}$ & $34.40 \pm 1.00 \mathrm{ab}$ \\
Cotton waste & $34.00 \pm 1.63 \mathrm{a}$ & $4.06 \pm 0.08 \mathrm{~b}$ & $1.60 \pm 0.04 \mathrm{a}$ & $6.53 \pm 0.13 \mathrm{c}$ & $7.33 \pm 0.23 \mathrm{~b}$ & $28.08 \pm 1.20 \mathrm{~b}$ \\
\hline
\end{tabular}

Values are expressed as means \pm standard error.

Means with different letters within columns are significantly $(p \leq 0.05)$ different according to least significant difference test. 
yield $(206.67 \mathrm{~g})$ was attained on cotton waste substrate. Our results are in agreement with the earlier reports of several scientists, who suggested wheat straw to get maximum yield of milky mushroom (Vijaykumar et al., 2014; Dayaram, 2009; Arora et al., 2004). In contrast to the present findings, rice straw is also reported to be a good substrate for milky mushroom cultivation (Biswas and Singh, 2009; Pani, 2010). The difference in the production potential of different substrates might be due to the variations in their physical properties and nutritional composition (Pani, 2010). The biological efficiency (\%) was significantly influenced by the substrates as shown in Table 2. The highest biological efficiency $(54.62 \%)$ was recorded in wheat straw while the lowest biological efficiency $(22.95 \%)$ was measured in cotton waste. These findings are regarding biological efficiency and total yield on wheat straw are in accordance with the results of previous studies (Doshi et al., 1993, 2007).

Nutritional composition (expressed on a dry weight basis) of $C$. indica fruit bodies, harvested from different substrates is presented in Table 3. The crude protein

Table 2. Effect of substrates on growth attributes such as total yield ( $\mathrm{g}$ ), biological efficiency (\%) of Calocybe indica

\begin{tabular}{lcc}
\hline Treatment & Total yield $(\mathrm{g} / \mathrm{bag})$ & Biological efficiency $(\%)$ \\
\hline Wheat straw & $493.67 \pm 18.66 \mathrm{a}$ & $54.627 \pm 1.91 \mathrm{a}$ \\
Rice straw & $332.00 \pm 12.09 \mathrm{~b}$ & $36.883 \pm 1.34 \mathrm{~b}$ \\
Cotton waste & $206.67 \pm 12.04 \mathrm{c}$ & $22.957 \pm 1.33 \mathrm{c}$ \\
\hline
\end{tabular}

Values are expressed as means \pm standard error.

Means with different letters within columns are significantly $(p \leq 0.05)$ different according to least significant difference test. content of mushroom fruiting body varied significantly among substrates. The highest protein content (23.66\%) was observed on wheat straw, while the minimum $(19.33 \%)$ on rice straw substrate. However, the moisture content of mushroom fruiting bodies harvested from different substrates was found to be non-significant (Table 3). The moisture content of mushroom fruiting bodies was noted in the range of $83-85 \%$. However, significant results were found regarding the ash content of fruiting bodies on various growing media (Table 3). The fruiting bodies harvested from wheat straw gave the maximum amount of ash contents $(10 \%)$ while the rice straw substrate gave the least amount. It has been known that the protein content of mushrooms varies with the type of substrate used due to the differential nature of the nutrient supply (Gothwal et al., 2012). Similarly, Gopinath et al. (2012) observed protein content in the range of 27.4-30.5, ash content 7.87-8.15 and moisture percentage $78-84.9 \%$ on different growing media. The results obtained in this study relate to the findings of Krishnamoorthy et al. (2000).

The N, P, K content significantly varied in fruiting bodies of mushrooms grown on different substrates (Table 3). The maximum $\mathrm{N}$ and $\mathrm{K}$ contents were present in mushroom grown on wheat straw substrate, among three different types of substrates, rice straw substrate gave the maximum amount of phosphorous in $C$. indica fruit bodies than other used substrates in this study. The findings of the present investigation are comparable to previous studies reported by different authors like Sharma et al. (2013) and Zahid et al. (2009).

\section{Substrates chemical analysis}

The substrates were analysed for their nutrient contents before and after cropping (Table 4). After 60 days of

Table 3. Effect of substrates on biochemical attributes such as N, P, K, Ash, moisture, protein of Calocybe indica mushroom fruiting bodies

\begin{tabular}{lcccccc}
\hline Treatments & $\begin{array}{c}\mathrm{N} \\
(\%)\end{array}$ & $\begin{array}{c}\mathrm{P} \\
\left(\mathrm{mg} \cdot 100 \mathrm{~g}^{-1}\right)\end{array}$ & $\begin{array}{c}\mathrm{K} \\
\left(\mathrm{mg} \cdot 100 \mathrm{~g}^{-1}\right)\end{array}$ & \multicolumn{1}{c}{$\begin{array}{c}\text { Ash } \\
(\%)\end{array}$} & $\begin{array}{c}\text { Moisture } \\
(\%)\end{array}$ & $\begin{array}{c}\text { Protein content } \\
(\%)\end{array}$ \\
\hline Wheat straw & $3.78 \pm 0.10 \mathrm{a}$ & $389.33 \pm 8.08 \mathrm{~b}$ & $1,966 \pm 62.60 \mathrm{a}$ & $10.00 \pm 0.40 \mathrm{a}$ & $85.00 \pm 0.81 \mathrm{a}$ & $23.67 \pm 0.62 \mathrm{a}$ \\
Rice straw & $3.09 \pm 0.10 \mathrm{~b}$ & $441.33 \pm 6.88 \mathrm{a}$ & $1,700 \pm 40.98 \mathrm{~b}$ & $7.33 \pm 0.85 \mathrm{~b}$ & $85.00 \pm 1.22 \mathrm{a}$ & $19.33 \pm 0.62 \mathrm{~b}$ \\
Cotton waste & $3.46 \pm 0.10 \mathrm{ab}$ & $356.33 \pm 4.51 \mathrm{c}$ & $1,400 \pm 40.98 \mathrm{c}$ & $8.33 \pm 0.62 \mathrm{~b}$ & $83.00 \pm 0.40 \mathrm{a}$ & $21.67 \pm 0.62 \mathrm{ab}$ \\
\hline
\end{tabular}

Values are expressed as means \pm standard error.

Means with different letters within columns are significantly $(p \leq 0.05)$ different according to least significant difference test.

Table 4. Biochemical analysis of substrates (waste materials) before and after cultivating mushroom

\begin{tabular}{|c|c|c|c|c|c|c|}
\hline \multirow[t]{2}{*}{ Treatment } & \multicolumn{2}{|c|}{ N (\%) } & \multicolumn{2}{|c|}{$\mathrm{P}(\%)$} & \multicolumn{2}{|c|}{ K (\%) } \\
\hline & Before cropping & After cropping & Before cropping & After cropping & Before cropping & After cropping \\
\hline Wheat straw & $1.123 \pm 0.039 b$ & $1.233 \pm 0.15 b$ & $0.760 \pm 0.008 b$ & $0.866 \pm 0.025 \mathrm{ab}$ & $1.170 \pm 0.014 b$ & $1.426 \pm 0.11 \mathrm{a}$ \\
\hline Rice straw & $0.993 \pm 0.008 b$ & $1.250 \pm 0.05 b$ & $0.683 \pm 0.01 \mathrm{c}$ & $0.816 \pm 0.040 \mathrm{~b}$ & $1.153 \pm 0.06 b$ & $1.396 \pm 0.12 \mathrm{a}$ \\
\hline Cotton waste & $1.500 \pm 0.04 \mathrm{a}$ & $1.586 \pm 0.12 \mathrm{a}$ & $0.853 \pm 0.01 \mathrm{a}$ & $1.013 \pm 0.113 \mathrm{a}$ & $1.353 \pm 0.008 \mathrm{a}$ & $1.566 \pm 0.08 \mathrm{a}$ \\
\hline
\end{tabular}

Values are expressed as means \pm standard error.

Means with different letters within columns are significantly $(p \leq 0.05)$ different according to least significant difference test. 
incubation with $C$. indica, the substrates were analysed for their NPK content. The highest $\mathrm{N}$ content, before cropping, was found in cotton waste than in other waste materials. The lignocellulosic waste materials after cropping, showed an increase in $\mathrm{N}$ content of substrates, among three substrates cotton waste showed the highest $\mathrm{N}$ values than other growing media. The phosphorous content in raw substrates was maximum in cotton waste and after cropping, phosphorous content remained highest in cotton waste while, found lowest in rice straw. After cropping $C$. indica the spent mushroom substrates gave an increase in potassium contents (Table 4). However, no significant difference in $\mathrm{K}$ contents was observed among substrates.

\section{Experiment 3}

\section{Effect of different casing materials on the yield and biological efficiency of milky mushroom}

The different casing materials (peat moss, loam soil and spent mushroom substrate) were tested for their effect on agronomic characteristics of $C$. indica. The results obtained are given in Table 5. Different casing materials showed significant differences from each other for producing a number of fruiting bodies per bag. The highest number of fruiting bodies per bag was harvested from peat moss casing followed by loam soil, while the lowest number of fruiting bodies was obtained from spent mushroom casing material. The maximum fresh weight of fruiting body was obtained from peat moss casing bags followed by loam soil casing bags, while the lowest weight of fruiting body was obtained from spent mushroom substrate casing. The total yield of $C$. indica differed significantly on different casing materials. Peat moss casing gave significantly higher yield along with higher biological efficiency, followed by loam soil casing, while spent mushroom substrate casing provided the lowest yield and biological efficiency. Casing was found to be an absolute requirement for proper fructification in $C$. indica by several workers. The present findings are in agreement with the findings of Ayyub et al. (2014) who also found peat moss as the best casing material. Moreover, Kerketta et al. (2018) uses various casing materials for the growth of milky mushroom and found that casing materials positively affected the growth and yield of mushroom. Casing soil protects the compost against desiccation, supports the mushroom against pests and diseases, provides support for developing sporophores and provides a gaseous exchange for growth and development of mushrooms (Colauto et al., 2011). The casing layer has microorganisms and provides an environmental change that helps mushrooms to shift from a vegetative stage to a reproductive stage (Gülser and Pekşen, 2003).

\section{Experiment 4}

\section{Effect of different supplements with wheat straw on the yield of milky mushroom}

A significant variation was observed in wheat bran and rice bran supplementation to wheat straw substrate on growth and yield of milky mushroom (Tables 6 and 7). Days required to complete mycelial running in substrates filled bags were minimum on wheat bran supplement while, in control highest days required to colonise substrate (Table 6). Stalk diameter was recorded highest in both wheat and rice bran supplemented substrates, while non-supplemented substrate (control) produced lowest stalk diameter mushrooms. The pileus (cap) diameter of fruiting body was found to be significantly higher on wheat bran supplemented substrate as

Table 5. Effect of casing materials on growth attributes of Calocybe indica fruiting body

\begin{tabular}{|c|c|c|c|c|}
\hline Treatment & $\begin{array}{c}\text { Biological efficiency } \\
(\%)\end{array}$ & $\begin{array}{l}\text { Fresh weight of } \\
\text { fruiting body }(\mathrm{g})\end{array}$ & $\begin{array}{l}\text { Number of } \\
\text { fruits/bags }\end{array}$ & $\begin{array}{l}\text { Total yield } \\
\text { (g/bag) }\end{array}$ \\
\hline Peat moss & $60.79 \pm 2.73 a$ & $41.07 \pm 0.65 \mathrm{a}$ & $15.33 \pm 0.40 \mathrm{a}$ & $547.18 \pm 24.65 \mathrm{a}$ \\
\hline Loam soil & $50.55 \pm 1.02 b$ & $37.99 \pm 0.60 \mathrm{ab}$ & $12.00 \pm 0.40 \mathrm{~b}$ & $455.01 \pm 9.23 b$ \\
\hline Spent mushroom substrate & $41.47 \pm 0.72 \mathrm{c}$ & $34.03 \pm 0.68 b$ & $11.00 \pm 0.40 b$ & $373.26 \pm 6.51 \mathrm{c}$ \\
\hline
\end{tabular}

Values are expressed as means \pm standard error.

Means with different letters within columns are significantly $(p \leq 0.05)$ different according to least significant difference test.

Table 6. Effect of supplements with wheat straw substrates on growth attributes of Calocybe indica mushroom fruiting bodies

\begin{tabular}{|c|c|c|c|c|}
\hline Treatment & $\begin{array}{c}\text { Biological efficiency } \\
(\%)\end{array}$ & $\begin{array}{l}\text { Fresh weight of } \\
\text { fruiting body }(\mathrm{g})\end{array}$ & $\begin{array}{l}\text { Number } \\
\text { fruit/bag }\end{array}$ & $\begin{array}{l}\text { Total yield } \\
\text { (g/bag) }\end{array}$ \\
\hline Wheat straw (control) & $43.62 \pm 2.42 \mathrm{c}$ & $35.99 \pm 1.09 b$ & $11.00 \pm 0.40 \mathrm{c}$ & $393.67 \pm 21.84 \mathrm{c}$ \\
\hline Wheat bran & $69.28 \pm 1.85 \mathrm{a}$ & $44.590 \pm 0.86 \mathrm{a}$ & $16.00 \pm 0.40 \mathrm{a}$ & $623.60 \pm 16.67 \mathrm{a}$ \\
\hline Rice bran & $58.75 \pm 0.84 b$ & $40.763 \pm 0.70 a$ & $14.00 \pm 0.40 b$ & $528.78 \pm 7.62 b$ \\
\hline
\end{tabular}

Values are expressed as means \pm standard error.

Means with different letters within columns are significantly $(p \leq 0.05)$ different according to least significant difference test. 
Table 7. Effect of supplements with wheat straw substrates on growth attributes of Calocybe indica mushroom fruiting bodies

\begin{tabular}{lcccc}
\hline Treatment & Mycelial running (days) & Stem length $(\mathrm{cm})$ & Pileus diameter $(\mathrm{cm})$ & Stem diameter $(\mathrm{cm})$ \\
\hline Wheat straw (control) & $26.33 \pm 0.62 \mathrm{a}$ & $7.10 \pm 0.08 \mathrm{c}$ & $4.88 \pm 0.09 \mathrm{c}$ & $1.70 \pm 0.08 \mathrm{~b}$ \\
Wheat bran & $20.21 \pm 0.62 \mathrm{~b}$ & $8.33 \pm 0.10 \mathrm{a}$ & $6.14 \pm 0.14 \mathrm{a}$ & $2.60 \pm 0.08 \mathrm{a}$ \\
Rice bran & $24.28 \pm 0.62 \mathrm{a}$ & $7.70 \pm 0.80 \mathrm{~b}$ & $5.44 \pm 0.10 \mathrm{~b}$ & $2.23 \pm 0.06 \mathrm{a}$ \\
\hline
\end{tabular}

Values are expressed as means \pm standard error.

Means with different letters within columns are significantly $(p \leq 0.05)$ different according to least significant difference test.

compared to non-supplemented substrate. The maximum number of fruiting bodies was obtained with wheat bran supplement, followed by rice bran, while the minimum was found with the non-supplemented substrate (Table 7). The equally maximum fresh weight of mushroom fruiting body was obtained with wheat bran and rice bran supplement. However, the minimum numbers were obtained from non-supplemented substrate (control).

The total yield obtained of milky mushroom per bag significantly varied with supplementing materials (Table 7). The maximum total yield was obtained with wheat bran supplement as compared to nonsupplemented substrate. The highest biological efficiency was obtained with wheat bran supplement followed by rice bran supplement. However, the lowest efficiency was noted in non-supplemented substrate (Table 7). These findings are in agreement with the outcome of Alam et al. (2010) who found that wheat bran supplement added with substrate increased the growth, yield and biological efficiency of milky mushroom. In addition, the effect of wheat bran supplement has also been reported in tropical and sub-tropical oyster mushrooms by Gurjar and Doshi (1995). The most common supplements are the sources of organic nitrogen such as cereal bran, which are necessary for the growth of the mycelial mass but may interfere with the productivity and biological efficiency of mushrooms. Similarly, Alam et al. (2010) reported that the addition of different supplements with the substrates influenced the spawn run, days for pinning, number of pinhead initiation, flushing pattern and overall mushroom yield.

\section{CONCLUSIONS}

Milky mushroom grows best at $30^{\circ} \mathrm{C}$ which is higher than required by other cultivated mushrooms. Regarding media used to culture the mycelium that is used for further spawn making, PDA is the best media. Among the locally available lignocellulosic substrates, wheat straw supplemented with wheat bran improved total yield and other agronomic and nutritional characteristics for milky mushroom production. Casing materials, such as peat moss, improved the quality as well as total yield of mushroom. In this study, peat moss proved to be the best casing material.

\section{ACKNOWLEDGEMENT}

The authors are grateful to Higher Education Commission (HEC) of Pakistan for financial support to this study under SRGP\#1071.

\section{FUNDING}

The research was supported by the HEC grant.

\section{AUTHOR CONTRIBUTIONS}

All authors contributed equally. H.S. planned and conducted the experiment and wrote the manuscript, M.A.A helps in reviewing the manuscript, A.N. and S. N. helped in designing and statistical analysis and S.E and S.A. helped in analysis.

\section{CONFLICT OF INTEREST}

The authors declare no conflict of interest.

\section{REFERENCES}

Alam, N., Amin, R., Khair, A., And Lee, T. S. (2010). Influence of different supplements on the commercial cultivation of milky white mushroom. Mycobiology, 38(3), 184-188.

Amin, R., Khair, A., Aiam, N., and Lee, T. S. (2010). Effect of different substrates and casing materials on the growth and yield of Calocybe indica. Mycobiology, 38(2), 97-101.

AOAC (Association of Official Analytical Chemists). (1990). Official methods of analysis. Rockville, MD: AOAC.

Arora, R. K., Mishra, K. K., Verma, R. C., And Singh, R. P. (2004). Evaluation of substrate for yield of Calocybe indica. Paper presented at the International Conference Mushroom Biology and Biotechnology 137, Cuernavaca, Morelos, Mexico.

Arshukla, C. (2004). Role of agronomical and biochemical parameters on growth and yield of Calocybe indica ( $P$ and $C$ ). Doctoral dissertation. Raipur, India: Indira Gandhi Agricultural University.

Ayyub, C. M., Khan, N. A., Rehman, A., Pervez, M. A., Akhtar, N., And Ullah, I. (2014). Evaluation of various casing materials for enhancing growth and yield of button mushroom (Agaricus bisporus 
Lange). Pakistan Journal of Phytopathology, 26(1), 125-132.

Biswas, S., And Singh, N. P. (2009). Evaluation of alternative substrates for milky mushroom. Journal of Mycology and Plant Pathology, 39(2), 355.

Chang, S. T. (2007). Mushroom cultivation using the ZERI principle: Potential for application. Micologia Aplicada International, 19(2), 33-34.

Chang, S. T. (2008). Overview of mushroom cultivation and utilization as functional foods. In P. C. K. Cheung (Ed.), Mushrooms as functional foods (pp. 1-33). New Jersey, USA: John Wiley \& Sons Inc.

Chapman, D. H., and Parker, F. (1961). Determination of NPK; methods of analysis for soil, plants and water. Publication Division Agriculture University California, USA, 150-179.

Colauto, N. B., Silveira, A. R. D., Eira, A. F. D., And Linde, G. A. (2011). Production flush of Agaricus blazei on Brazilian casing layers. Brazilian Journal of Microbiology, 42(2), 616-623.

Dayaram. (2009). Cultivation of milky white mushroom in Bihar, India. Journal of Mycology and Plant Pathology, 39, 283-285.

Dhakad, P. K., Chandra, R., Yadav, M. K., And PAtar, U. R. (2015). Comparative study on growth parameters and yield potential of five strains of milky mushroom (Calocybe indica). Journal of Pure and Applied Microbiology, 9(3), 2333-2338.

Doshi, A., And Sharma, M. (2007). Prospects of cultivation of specialty mushrooms in Rajasthan, India. Mushroom Biology and Biotechnology, 213, 293.

Doshi, A., Sharma, S. S., and Trivedi, A. (1993). A promising edible mushroom for the tropics Calocybe indica P. \& C. Mushroom Info, 86, 14-22.

Gopinath, L., Arunkumar, J., Meera, A., and Raj, S. P. (2012). Optimization of growth parameters for increased yield of the edible mushroom Calocybe indica. African Journal of Biotechnology, 11(30), 7701-7710.

Gothwal, R., Gupta, A., Kumar, A., Sharma, S., And Alappat, B. J. (2012). Feasibility of dairy waste water (DWW) and distillery spent wash (DSW) effluents in increasing the yield potential of Pleurotusflabellatus (PF 1832) and Pleurotus sajor-caju (PS 1610) on bagasse. 3 Biotech, 2, 249-257.

Gülser, C., And Pekşen, A. (2003). Using tea waste as a new casing material in mushroom (Agaricus bisporus (L.) Sing.) cultivation. Bioresource Technology, 88(2), 153-156.

GurJar, K. L., AND Doshi, A. (1995). Effect of substrates and supplements on fruit bodies production of Pleurotus cornucopiae (Paul ex Pers) Rolland. Mushroom Information, 12, 12-22.

Hoa, H. T., Wang, C. L. And Wang, C. H. (2015). The effects of different substrates on the growth, yield, and nutritional composition of two oyster mushrooms
(Pleurotus ostreatus and Pleurotus cystidiosus). Mycobiology, 43, 423-434.

KADIRI, M. (1999). Production of grain mother and planting spawns of Lentinus subnudus Berk. Bioscience Biotechnology Research Communications, 11(4), 307-314.

Kerketta, A., Pandey, N. K., Singh, H. K., and Shukla, C. S. (2018). Effect of straw substrates and casing materials on yield of milky mushroom (Calocybe indica P\&C.) strain CI-524. International Journal of Current Microbiology and Applied Science, 7(2), 317-322.

Krishnamoorthy, A. S., Muthuswamy, M. T., And NAKkeERAN, S. (2000). Technique for commercial production of milky mushroom Calocybe indica P\&C. Indian Journal of Mushroom, 18, 19-23.

Kumar, R., Singh, G., Mishra, P., And Singh, R. (2012). Effect of different organic supplements and casing mixtures on yield of two strains of milky mushroom (Calocybe indica). Indian Phytopath, 65, 399-403.

Kurtzman, R. H. JR. (2005). Mushrooms: Sources for modern western medicine. Micologia Aplicada International, 17(2), 21-33.

Mattila, P., Könkö, K., Eurola, M., Pihlava, J. M., Astola, J., Vahteristo, L., And Pirronen, V. (2001). Contents of vitamins, mineral elements, and some phenolic compounds in cultivated mushrooms. Journal of Agricultural and Food Chemistry, 49(5), 2343-2348.

Miles, P. G., And Chang, S. T. (2004). Mushrooms: Cultivation, nutritional value, medicinal effect, and environmental impact. Boca Rotan, Florida: CRC Press.

Pani, B. K. (2010). Evaluation of some substrates for cultivation of white summer mushroom (Calocybe indica). Research Journal of Agricultural Sciences, 1(4), 357-359.

Pardo, A., González, J. E. P., Pardo, J., and DE Juan, A. J. (2004). Assessment of different casing materials for use as peat alternatives in mushroom cultivation: Evaluation of quantitative and qualitative production parameters. Spanish Journal of Agricultural Research, 2(2), 267-272.

Patel, Y., Naraian, R., and Singh, V. K. (2012). Medicinal properties of Pleurotus species (oyster mushroom): A review. World Journal of Fungal and Plant Biology, 3(1), 1-12.

Raghuramulu, N., Madhavan, N. K., And Kalyansundaram, S. (2003). A manual of laboratory techniques (pp. 319-320). Hyderabad, India: National Institute of Nutrition, ICMR.

Royse, D. J., Rhodes, T. W., Ohga, S., And SAnchez, J. E. (2004). Yield, mushroom size and time to production of Pleurotus cornucopiae (oyster mushroom) grown on switch grass substrate spawned and supplemented at various rates. Bioresource Technology, 91(1), 85-91. 
Ruiz-Rodríguez, A., Polonia, I., Soler-Rivas, C., AND Wichers, H. J. (2011). Ligninolytic enzymes activities of Oyster mushrooms cultivated on OMW (olive mill waste) supplemented media, spawn and substrates. International Biodeterioration \& Biodegradation, 65(2), 285-293.

Sardar, H., Ali, M. A., Ayyub, C. M., and Ahmed, R. (2015). Effects of different culture media, temperature and $\mathrm{pH}$ levels on the growth of wild and exotic Pleurotus species. Pakistan Journal of Phytopathology, 27(2), 139-145.

Sardar, H., Ali, M. A., Anuum, M. A., Nawaz, F., Hussain, S., Naz, S., and Karimi, S. M. (2017). Agro-industrial residues influence mineral elements accumulation and nutritional composition of king oyster mushroom (Pleurotus eryngii). Scientia Horticulturae, 225, 327-334.

Sharma, S. K., Lall, A. M., and Lal, A. A. (2013). Effect of various organic supplements on nonenzymatic antioxidant and minerals expression in Calocybe indica. The Bioscan, 8(2), 421-424.

Shukla, S., AND Jaitly, A. K. (2013). Effect of temperature on mycelial growth of different strains of Calocybe indica mushroom. Online International Journal of Biosolution, 3(1), 121-123.

Singh, V. P., Singh, G., Singh, V. P., Kumar, A., Bhople, B. S., Srivastava, S., Kumar, A., and Singh, P. (2015). Effect of different temperatures and $\mathrm{pH}$ on radial growth of different strains of Calocybe indica. Research Journal of Pharmaceutical Biological and Chemical Sciences, 6(5), 1016-1019.
StAmeTs, P. (2011). Growing gourmet and medicinal mushrooms. Bekerly, Toronto, Canada: Ten Speed Press.

Subbiah, K. A., and Balan, V. (2015). A comprehensive review of tropical milky white mushroom (Calocybe indica P\&C). Mycobiology, 43(3), 184-194.

Thakur, M. P., And Singh, H. K. (2014). Advances in the cultivation technology of tropical mushrooms in India. JNKVV Research Journal, 48(2), 120-135.

VARSHNEY, A. (2007). Variability among the strains of Calocybe indica (P\&C). M. Sc. (Agriculture). Thesis. Pantnagar: GBPUA\&T, 94.

Vijaykumar, G., John, P., and Ganesh, K. (2014). Selection of different substrates for the cultivation of milky mushroom (Calocybe indica $P \& C$ ). International Journal of Knowledge Transfer, 13, 434-436.

YADAV, R. S. (2006). Use of vermiproducts in the cultivation of milky mushroom (Calocybe indica). Doctoral dissertation. Dharwad, India: UAS.

Zadrazil, F. (1978). Cultivation of Pleurotus. In S. T. Chang And W. A. Hayes (Eds), The biology and cultivation of edible mushrooms (Vol. 1, 62, pp. 512-558). Orlando, FL, USA: Academic Press.

Zahid, M. K., Barua, S., And Haque, S. I. (2009). Proximate composition and mineral content of selected edible mushroom varieties of Bangladesh. Bangladesh Journal of Nutrition, 22-23, 61-68.

Received November 23, 2019; accepted May 13, 2020 